\title{
PECAN SHELLING BY-PRODUCT AS A PARTIAL REPLACEMENT FOR CORN IN SWINE DIETS: PERFORMANCE, DIETARY ENERGETICS AND SAFETY ASSESSMENT
}

\author{
Lorenzo BUENABAD ${ }^{1 \times}$, Edith SAENZ1 ${ }^{1}$, Néstor ARCE², Juan GONZALEZ ${ }^{2}$, José Alfredo MARTINEZ1 and \\ Agustín CORRAL1
}

${ }^{1}$ Facultad de Zootecnia y Ecología, Universidad Autónoma de Chihuahua, Chihuahua, 31453, México

2Instituto de Ciencias Agrícolas, Universidad Autónoma de Baja California, Mexicali 21100, México

Email: Ibuenabad@uach.mx; (D)RCiD: 0000-0002-0271-4088

supporting Information

ABSTRACT: The objective of the present study was to evaluate the pecan shelling by-product (PSB) grindings as partial replacement for corn in swine diets and its exerting effect on sows' performance. Seventeen pregnant sows (210 kg of initial body weight) were used in a 14-d trial to evaluate the effect of partial replacement of corn with PSB on performance, dietary energetics, and safety. Treatments consisted of cornsoybean meal-based diet containing 0 or $10 \%$ of PSB in the diet, where the later replaced 0 or $16 \%$ of corn (as-fed basis). Ether extract (EE) content on PSB averaged $185 \mathrm{~g} / \mathrm{kg}$. Treatments including PSB had 1.9 times the EE compared to the treatment with only corn-soybean meal. Replacement of $16 \%$ of corn with PSB increased the estimated digestible (DE) and metabolizable energy (ME) values of the diet by 218 and 230 $\mathrm{kcal} / \mathrm{kg}$ compared to control diet (90\% DM basis), respectively. The higher predicted DE or ME intake for sow fed on PSB diet were 500 or $529 \mathrm{kcal} /$ day compared to control diet, respectively; however, no differences on average daily gain $(0.52 \mathrm{~kg} / \mathrm{d})$ between dietary treatments were observed. Neither was feed refusal for any dietary treatment nor difference on finishing their respective feed allowance. Sows consumed pecan shell at level of $0.75 \mathrm{~g} / \mathrm{kg}$ of body weight daily, approximately. Intestinal activity was not affected by PSB consumption and fecal score averaged 3.0. Partial replacement of corn with PSB increased the estimated DE and $\mathrm{ME}$ for gestating diets by $7 \%$, without influencing performance and intestinal function. The pecan shelling by-product supplementation at $10 \%$ inclusion level into a corn-soybean meal-based diet does not affect performance and its addition to the diet contributes to a more sustainable use of locally available feedstock in swine feeding.

Keywords: By-product, Corn-soybean meal, Pecan; Pigs, Sows diet.

\section{INTRODUCTION}

Food production from livestock systems demands considerable resources such as land, water, and fuel. Additionally, this industry emits industrial contaminants that have long term ramifications unless actions are taken (Grossi et al., 2019). Livestock feeding accounts for roughly over 60 to $70 \%$ of total animal production cost (Zijlstra and Beltranena, 2013; Pomar and Remus, 2019) and rely heavily on commodities such as soybean and corn that are produced far from feeding operations (Wilfart et al., 2016, Mendes dos Reis et al., 2020). This has been the case over the last half century, as cornsoybean meal-based swine diet formulations promote better performance for growing and mature pigs compared to other cereal grains (Stein et al., 2016). The feed, food and fuel industry compete for corn which can jeopardize food security and social stability; this is especially important to Mexico where corn is a staple food (0'leary, 2016). Therefore, it is important to look for alternative feedstocks to reduce dependency on corn in feed formulations (Muscat et al., 2020). Across the world, local agro-food-industries generate several by-products that can be used in swine feeding (Zijlstra and Beltranena, 2013). The pecan shelling industry in northern Mexico generates by-products such as pecan shelling by-product grindings (PSB; "polvillo de nuez") which is rich in fat and polyphenol content (De la Rosa et al., 2011). The PSB chemical composition varies widely (Flores-Córdova, et al., 2016) which might be attributed to its parent feedstock composition variability and further amplified by processing related factors (Zijlstra and Beltranena, 2009). At present, PSB remains underutilized as a feedstock for animal feeding. A major research area is developing to evaluate its polyphenol components for biomedical purposes (Flores-Estrada et al., 2020). Based on its proximate components, the inclusion of PSB into swine diet formulations is expected to be comparable to the nutritional value of the replaced corn. Additionally, the inclusion of PSB in swine diets is expected to have a positive impact on feed and environmental cost. However, the suitability of PSB for swine diets is unknown. Hence, the objective of the present study was to evaluate the PSB as partial replacement for corn in swine diets and its exerting effect on sows' performance. 


\section{Animal handling, housing, and feeding}

Seventeen pregnant sows (five gilts and twelve sows; York $\times$ Landrace $\times$ Duroc) were used to evaluate the effect of partial replacement of corn by pecan shelling by-product grindings (PSB) on sows' performance during midgestation (from d 53 to 67). Gilts were supplemented with altrenogest (Virbagest ${ }^{\circledR}$, Virbac Mexico, S.A de C.V.) for oestrous synchronization and artificially inseminated with at least two doses of a semen of mature boar of proven fertility. Sows were bred using artificial insemination following oestrus detection after weaning. After pregnancy diagnosis, sows and gilts were randomly assigned to one of two dietary treatments. Sows were not re-grouped and kept in their same pen of origin ( 3 to 5 sows) to prevent changes in social ranking within each group. The sows used in this trial were cared for in accordance with the guidelines established in the Official Mexican Regulations on Animal Care (NOM-062-Z00-1999, 2001). Experimental diets were based on corn-soybean meal supplemented with vitamins and minerals and formulated to meet or exceed nutrient requirements of pregnant sows (NRC, 2012). Dietary treatments (Table 1) were as follows: T1; corn-soybean meal diet (CTL) and T2; corn-soybean meal diet containing 10\% of PSB, where the later replaced $16 \%$ of corn (as-fed basis). Pens were $54 \mathrm{~m}^{2}$ with $36 \mathrm{~m}^{2}$ overhead shade, nipple drinker, and $5 \mathrm{~m}$ concrete feeder bunk. Sows were fed $2.3 \mathrm{~kg}$ per sow once a day in the mornings $(0800 \mathrm{~h})$ and were allowed free access to drinking water. Initial and final body weights (BW) were recorded to calculate the average daily gain (ADG). Including a non-conventional feedstock into the diet can generate unintended consequences on intestinal activity such a diarrhea or constipation, thus every morning fecal score was monitored by pen for the whole period. Fecal score ranged from zero to five: 0 , total absence of feces; 1 , dry and hard; 2, between dry and soft; 3, soft but still formed; 4, soft and wet; 5, liquid feces (Oliviero et al., 2010).

\section{Sample analysis and Estimation of dietary energy}

Pecan shelling by-product and feed samples were subject all or in part to the following analysis: DM (oven drying at $105^{\circ} \mathrm{C}$ until no further weigh lost; method 930.15; AOAC, 2000), ash (method 942.05, AOAC, 2000), Kjeldahl N (method 984.13, AOAC, 2000); crude fiber (method Ba 6a-05; AOCS, 2005) and ether extract (Thiex et al., 2003). Dietary digestible and metabolizable energy values were estimated using the values of dietary proximal components fed on prediction equation for growing pigs (Noblet and Perez, 1993), and subsequently the intermediate results were applied into a second prediction equation for sows (Noblet and Shi, 1993).

\section{Statistical design and analysis}

The data from this trial was analyzed as a randomized block design experiment using PROC GLM procedure (SAS Inst. Inc., Cary NC; Version 9.1), considering parity for blocks, and sows as experimental unit according to the following statistical model: $Y_{i j}=\mu+\beta_{i}+T_{j}+E_{i j}$

Where $\mu$ is the common experimental effect; $\beta_{i}$ represents parity; $T_{i}$ represents the dietary treatment effect; $E_{i j}$ represents the residual error. Treatments effects were evaluated by means of t-test.

\section{RESULTS AND DISCUSSION}

\section{Dietary nutrient content of pecan shelling by-product grindings}

The pecan shelling industry's main product is half pecan kernels of different grading, but the industry also generates by-products such as shell and pecan shelling by-product grindings. The average PSB is composed of shattered pecan kernel pieces in combination with shelling grindings which are rich in fatty acids (Sevimli-Gur et al., 2021) and polyphenol content (De la Rosa et al., 2011), respectively. As expected, the analyzed ether extract (EE) content on PSB was high, averaging $185 \mathrm{~g} / \mathrm{kg}$ (Table 2); the EE value of PSB was five times higher than that of tabulated fat values on replaced corn (as-fed basis; NRC 2012). It is well known that pecan fat and polyphenol content is highly variable, which is influenced by production year (Flores-Córdova et al., 2016), place of origin (De la Rosa et al., 2011), and cultivar (Cason et al., 2021). In this regard, the estimation of nutrient content on by-products such as PSB might be challenging and make it difficult to predict its influence on animal performance. In fact, the inclusion of PSB on backyard pig's diets led to unsuccessful animal performance. The basis of this is not certain, but the uncontrolled level of inclusion of this feedstock into the pig's diets plays a major role. The fat component in pecan nut contains roughly 65,27 , and $7 \%$ of monounsaturated, polyunsaturated, and saturated fatty acids, respectively (Rivera-Rangel et al., 2018). The consumption of residual fat in PSB seems energetically and metabolically important to improve sow's performance on her current pregnancy (MetzlerZebeli, 2021). However, polyphenols are considered "antinutritional factors" which influence feed palatability (Windisch et al., 2008; Huang et al., 2018; Caprarulo et al., 2021) and nutrient digestibility (Bravo, 1998). Conversely, it also exerts antiparasitic, antimicrobial and antioxidant activity (Huang et al., 2018). The high content of bioactive compounds with antimicrobial activity in PSB (Cason et al., 2021) leads us to assume that this is a suitable feedstock to replace conventional growth promotion additives in swine production (Huang et al., 2018; Flores-Estrada et al., 2020; Cason et al., 2021). Likewise, the antioxidant activity of polyphenols can help to counteract the reactive oxygen species (ROS) production during periods of stress (Flores-estrada et al., 2020), a common condition for sows reared under intense animal production setting (Agyekum and Nyachoti, 2017). 
Table 1 - Ingredients and composition of experimental diets fed to gestating sows as is.

\begin{tabular}{|c|c|c|}
\hline Item & Control & PSB, $10 \%$ \\
\hline Corn & 61.5 & 51.5 \\
\hline Soybean meal & 10.0 & 10.0 \\
\hline Wheat bran & 24.0 & 24.0 \\
\hline Pecan shelling by-product grindings & 0.0 & 10.0 \\
\hline Canola oil & 1.5 & 1.5 \\
\hline \multirow[t]{2}{*}{ Feed supplement } & 3.0 & 3.0 \\
\hline & 100.0 & 100.0 \\
\hline \multicolumn{3}{|l|}{ Analyzed composition } \\
\hline Dry matter & 91.4 & 92.5 \\
\hline Crude Protein & 15.7 & 16.3 \\
\hline Crude fiber & 6.5 & 5.7 \\
\hline Ether extract & 4.3 & 8.3 \\
\hline Ash & 6.3 & 6.4 \\
\hline \multicolumn{3}{|l|}{ Estimated dietary energy } \\
\hline Digestible energy, kcal.kg-1 & 3334 & 3552 \\
\hline Metabolizable energy, kcal.kg-1 & 3110 & 3340 \\
\hline
\end{tabular}

\section{Table 2 - Proximate composition of pecan shelling by-product grindings (g.kg-1 as-fed basis).}

\begin{tabular}{lccc} 
Item & N & Mean & SD \\
Dry matter & 3 & 929.6 & 6.9 \\
Crude protein & 2 & 178.0 & 1.4 \\
Crude fiber & 1 & 230.1 & - \\
Ether extract & 2 & 184.8 & 6.2 \\
Ash & 2 & 16.6 & 0.4 \\
\hline
\end{tabular}

\section{Estimated dietary energetics on gestating diets}

All nutrients are equally important for swine diet formulation; however amino acids, phosphorus, and energy are considered the most expensive components in swine diet formulations (Noblet and Perez, 1993; Velayudhan et al., 2015; Stein et al., 2016). In this regard, underutilized feedstock such as a good quality PSB could be a valuable nonconventional feed ingredient for swine diet formulations; this is especially true under the forecasted energetic conventional feedstuffs shortage (Velayudhan et al., 2015). Based on its proximate components, the estimated digestible energy (DE) values of dietary treatments were 3334 and $3552 \mathrm{kcal} / \mathrm{kg}$ (90\% DM basis) for control and PSB supplemented diet, respectively (Table 1; Noblet and Perez, 1993; Noblet and Shi, 1993). Similarly, the estimated metabolizable energy (ME) values for control and PSB supplemented diet were 3110 and $3340 \mathrm{kcal} / \mathrm{kg}$ (90\% DM basis), respectively (Noblet and Perez, 1993; Noblet and Shi, 1993). The higher EE content in PSB increased corresponding EE content in the tested dietary treatment, which was 1.9 times higher than that in control diet. However, the corresponding estimated dietary DE and ME on the PSB supplemented diet was just $7 \%$ higher compared to the control diet in both cases. The basis of this is not certain. As dietary EE content increases, its digestibility improves until fat content is greater than $80 \mathrm{~g} / \mathrm{kg}$ of $\mathrm{DM}$ (Noblet and Shi, 1993) as in this case ( $89 \mathrm{~g} / \mathrm{kg}$ of DM) which limits dietary energy utilization by the sow. One way to solve this issue could be to reduce or remove total supplemental vegetable oil in the diet itself to increase fat digestion from PSB which would reduce the feed cost even further.

\section{Non-conventional feedstock dietary supplementation on sows' performance}

Local agro-industrial by-products from fruits and vegetable processing around the world are gaining interest as an environmentally friendly strategy for animal feeding (Correddu et al., 2020). The aim is to reduce dependency on commodities shipped long distances to reduce carbon footprint of transportation (De Quelen, et al., 2021). Commodities such as corn and soybean meal have a substantial influence on cost of diet formulations even at levels of inclusion as low as $10 \%$ (Wilfart et al., 2016). In close agreement with the estimated dietary DE or ME values on dietary treatments, average daily gain in sows was not different between treatment groups, which averaged $0.52 \mathrm{~kg} / \mathrm{d}$ (Table 3). This is within normal range values for sows reared under similar conditions (Deng et al., 2021). However, sows on the PSB treatment had numerically greater average daily gain (29\%) compared to those on the control diet. The last is consistent with the slight improvements on DE and ME on the PSB supplemented diet. The high variation on ADG within groups is ascribed to the difference in feed intake. This is the result of hierarchical system within each group of pigs where low-ranking sows 
are in disadvantage compared to high-ranking sows at feeding time (Bench et al., 2013). Group housing gestating sows aimed to improve sows ' welfare (Norring et al., 2018). With legislation moving away from the use of stalls (Greenwood et al., 2014), figuring out how to feed sows on forecasted production scenarios is important (Deng et al., 2019).

Table 3 - Treatment effects on performance of gestating sows.

\begin{tabular}{|c|c|c|c|c|}
\hline Experimental groups & Control & PSB, 10\% & SEM & P-Value \\
\hline Body weight at $53 \mathrm{~d}$ of gestation, $\mathrm{kg}$ & 210.9 & 210.4 & 8.742 & $>0.10$ \\
\hline Body weight at $67 \mathrm{~d}$ of gestation, $\mathrm{kg}$ & 217.2 & 218.6 & 8.669 & $>0.10$ \\
\hline Average daily gain, $\mathrm{kg}$ & 0.45 & 0.58 & 0.162 & $>0.10$ \\
\hline Fecal score & 3.0 & 2.9 & 0.035 & $>0.10$ \\
\hline
\end{tabular}

\section{General safety assessment of pecan shelling by-product fed on swine}

As a non-conventional feedstock, PSB presents some challenges that need to be addressed to safely recommend its inclusion in feed formulations. The safety assessment starts by completing a comparative evaluation of candidate feedstock (pecan shelling by-product; PSB) with a comparable feed (corn) that has a known history of safe use in animal feeding (Glenn, 2008). As described, there were no issues on sows' performance when they were fed a PSB supplemented diet. Gestating sows are fed to meet or exceed their nutritional requirements but not to the point of meeting satiety (Greenwood et al., 2019). In this management system, gestating sows are less selective of unpalatable feed (Agyekum and Nyachoti, 2017). In this trial, sows fed the PSB supplemented diet did not show any refusal from their feed allowance, even when the tested diet was high on polyphenol content. No differences $(P>0.05)$ were observed between treatment groups for time spent eating. Conversely, lactating sows fed ad libitum took longer to finish their feed allowance when PSB was included at levels as low as $2.5 \%$ of the diet (as-fed basis; unpublished data). Constipation is a recurrent problem in sows which is influenced by level of feed and water intake, diet composition and their interactions between them with the intestinal microbiota (Pearodwong et al., 2016). Unattended constipation can lead to poor performance around farrowing and during lactation (Oliviero et al., 2010). Fecal score was not different between treatment groups which averaged 2.9 and $\mathbf{3 . 0}$ for PSB supplemented and control diet, respectively. Based on average feed intake and PSB composition, sows consumed approximately $0.75 \mathrm{~g} / \mathrm{kg}$ of BW of pecan shell which corresponded to $14 \%$ of pecan shell supplemented to rats where the maximum safe consumption recommendation for humans came from (Dolan et al., 2016).

\section{CONCLUSIONS}

Partial replacement of corn with pecan shelling by-product grindings increased the estimated DE and ME for gestating diet by 7\%; however, it did not influence sows' performance at mid-gestation period. Based on the estimated dietary energetics, the PSB energy value seems to be comparable to that of corn for mature pigs. Furthermore, no clinical signs of health problems were seen during the trail. In agreement with sows' performance, estimated dietary energetics, and corn use reduction (16\%), PSB can be included into sows' diet at the $10 \%$ level when replacing corn. This feeding strategy can contribute to the sustainable use of locally available feedstock in swine feeding, without affecting their productive performance.

\section{DECLARATIONS}

\section{Corresponding author}

Lorenzo BUENABAD; E-mail: Ibuenabad@uach.mx; DORCID: 0000-0002-0271-4088

\section{Acknowledgment}

Appreciation is expressed to Programa para el desarrollo profesional docente (PRODEP) [the program for the professional development of teachers] Mexico, for financial support to L. Buenabad.

\section{Conflict of interest}

The authors declare no conflict of interest.

\section{Authors' contributions}

Buenabad L. conceived and designed the study, reviewed the manuscript, and gave final approval of the submitted version of this manuscript. Saenz E. participated with data acquisition, analyzed, and interpreted the data. Arce N., Gonzalez J., and Corral A. analyzed and interpreted the data, and edited the manuscript for important intellectual contents. Martinez J.A. participated with data acquisition and critically revised the manuscript for improvements. 


\section{REFERENCES}

Agyekum A and Nyachoti CM (2017). Nutritional and metabolic consequences of feeding high-fiber diets to swine: a review. Engineering, 3(5):716-725. http://dx.doi.org/10.1016/J.ENG.2017.03.010

AOAC (2000). Association of official analytical chemists. Official methods of analysis. $17^{\text {th }}$ Edition. Gaithersburg, MD

AOCS. 2005. The American Oil Chemists Society. Official methods and recommended practices of AOcS. 5th Edition. Champaign, IL

Bench CJ, Rioja-Lang FC, Hayne SM and Gonyou HW (2013). Group gestation sow housing with individual feeding-II: how space allowance, group size and composition, and flooring affect sow welfare. Livestock Science, 152(2-3):218-227. http://dx.doi.org/10.1016/j.livsci.2012.12.020

Bravo L (1998). Polyphenols: chemistry, dietary sources, metabolism, and nutritional significance. Nutritions Reviews, 56(11):317-333. DOI: https://doi.org/10.1111/j.1753-4887.1998.tb01670.x

Caprarulo V, Giromini C and Rossi L (2021). Review: Chestnut and quebracho tannins in pigs nutrition: the effects on performance and intestinal health. Animal, 15(1):100064. https://doi.org/10.1016/i.animal.2020.100064

Cason C, Yemmireddy VK, Moreira J and Adhikari A (2021). Antioxidant properties of pecan shell bioactive components of different cultivars and extraction methods. Foods, 10:217. https://doi.org/10.3390/foods10040713

Correddu F, Lunesu MF, Buffa G, Atzori AS, Nudda A, Battacone G and Pulina G (2020). Can agro-industrial by-products rich in polyphenols be advantageously used in feeding and nutrition of dairy small ruminants? Animals, 10:131. DOI: https://doi.org/10.3390/ani10010131

De la Rosa LA, Alvarez-Parrilla E and Shahidi F (2011). Phenolic compounds and antioxidant activity of kernels and shells of mexican pecan (Carya illinoinensis). Journal of Agriculture and Food Chemistry, 59(1):152-162. DOI: https://doi.org/10.1021/if1034306

De Quelen F, Brossard L, Wilfart A, Dourmad JY and Garcia-Launay F, (2021). Eco-friendly feed formulation and on-farm feed production as ways to reduce the environmental impacts of pig production without consequences on animal performance. Frontiers in Veterinary Science, 8: 689012. DOI: https://doi.org/10.3389/fvets.2021.689012

Deng J, Cheng C, Yu H, Haung S, Hao X, Chen J, Yao J, Zou J and Tan C (2021). Inclusion of wheat aleurone in gestation diets improves postprandial satiety, stress status and stillbirth rate of sows. Animal Nutrition, 7(2):412-420. https://doi.org/10.1016/j.aninu.2020.06.015

Dolan L, Matulka R, Worn J and Nizio J (2016). Safety studies conducted on pecan shell fiber, a food ingredient produced from ground pecan shells. Toxicology Reports, 3:87-97. http://dx.doi.org/10.1016/i.toxrep.2015.11.011

Flores-Córdova MA, Berzoza-Vasquez P, Sánchez-Chávez E, Solís JIS, Guerrero-Morales S and Hernández-Carrillo J (2016). Composición fisicoquímica y capacidad antioxidante del fruto del pecanero en condiciones de año de elevada producción ("on") y de año de baja producción ("off") [Physico-chemical composition and antioxidant capacity of the pecan fruit in high (on) and low-productive conditions (of)]. Informacion Tecnica Economica Agraria, 112(3): 255-270. https://doi.org/10.12706/itea.2016.016

Flores-Estrada RA, Gámez-Meza N, Medina-Juárez LA, Castillón-Campaña LG, Molina-Domínguez CC, Rascón-Valenzuela LA and García-Galaz A (2020). Chemical composition, antioxidant, antimicrobial and antiproliferative activities of wastes from pecan nut [Carya illinoinensis (Wagenh) K. Koch]. Waste and Biomass Valorization, 11:3419-3432. D0I: https://doi.org/10.1007/s12649-019-00681-2

Glenn KC (2008). Nutritional and safety assessment of foods and feeds nutritionally improved through biotechnology-case studies by the international food biotechnology committee of ILSI. Asia Pacific Journal of Clinical Nutrition, 17(S1): 229-232. https://pubmed.ncbi.nlm.nih.gov/18296343/ I PMID: 18296343

Greenwood EC, Plush KJ, Van Wettere WHEJ and Hughes PE (2014). Hierarchy formation in newly mixed, group housed sows and management strategies aimed at reducing its impact. Applied Animal Behavior Science, 160: 1-11. http://dx.doi.org/10.1016/j.applanim.2014.09.011

Grossi G, Goglio P, Vitali A and Williams AG (2018). Livestock and climate change: impact of livestock on climate and mitigation strategies. Animal Frontiers, 9(1):69-76. https://doi.org/10.1093/af/vfy034

Huang Q, Liu X, Zhao G, Hu T and Wang Y (2018). Potential and challenges of tannins as an alternative to in-feed antibiotics for farm animal production. Animal Nutrition, 4(2):137-150. https://doi.org/10.1016/j.aninu.2017.09.004

Mendes dos Reis JG, Sanches Amorim P, Sarsfield Pereira Cabral JA and Toloi RC (2020). The impact of logistics performance on Argentina, Brazil, and the US soybean exports from 2012 to 2018: A gravity model approach. Agriculture, 10:338. DOI: https://doi.org/10.3390/agriculture10080338

Metzler-Zebeli BU (2021). The role of dietary and microbial fatty acids in the control of inflammation in neonatal piglets. Animals, 11: 2781. DOI: https://doi.org/10.3390/ani11102781

Muscat A, de Olde EM, de Boer IJM and Ripoll-Bosch R (2020). The battle for biomass: a systemic review of food-feed-fuel competition. Global Food Security, 25: 100330. https://doi.org/10.1016/i.gfs.2019.100330

Noblet J and Perez JM (1993). Prediction of digestibility of nutrients and energy values of pigs diets from chemical analysis. Journal of Animal Science, 71(12): 3389-3398. https://doi.org/10.2527/1993.71123389x

Noblet J and Shi XS (1993). Comparative digestibility of energy and nutrients in growing pigs fed ad libitum and adult sows fed at maintenance. Livestock Production Science, 34(1-2):137-152. DOI: https://doi.org/10.1016/03016226(93)90042-G

NOM-062-Z00-1999 (2001). Norma oficial mexicana. Especificaciones técnicas para la producción, cuidado y uso de los animales de laboratorio. Diario oficial de la federación. Ciudad de México, México [Official mexican standards. 
Technical specifications for the production, care, and use of laboratory animals. Official gazette of the federation. Mexico city, Mexico]. https://www.gob.mx/cms/uploads/attachment/file/203498/NOM-062-Z00-1999_220801.pdf

Norring M, Valros A, Bergman P, Marchant-Forde JN and Heinonen M (2018). Body condition, live weight and success in agonistic encounters in mixed parity group of sows during gestation. Animal, 13(2):392-398. DOI: https://doi.org/10.1017/S1751731118001453

NRC (2012). Nutrient requirements of swine. National Research Council, National Academic Press, 12th Edition. Washington, DC. DOI: https://doi.org/10.17226/13298

O'Leary M (2016). Maize: from Mexico to the world. International maize and wheat improvement center, Mexico. Link: https://www.cimmyt.org/blogs/maize-from-mexico-to-the-world/

Oliviero C, Heinonen M, Valros A and Peltoniemi 0 (2009). Environmental and sow-related factors affecting the duration of farrowing. Animal Reproduction Science, 119 (1-2):85-91. DOI: https://doi.org/10.1016/i.anireprosci.2009.12.009

Pearodwong P, Muns R and Tummaruk P (2016). Prevalence of constipation and its influence on post-parturient disorders in tropical sows. Tropical Animal Health and Production, 48:525-531. https://doi.org/10.1007/s11250-015-0984-3

Pomar C and Remus A (2019). Precision pig feeding: a breakthrough toward sustainability. Animal Frontiers, 9(2):52-59. https://doi.org/10.1093/af/vfz006

Rivera-Rangel LR, Aguilera-Campos KI, Garcia-Triana A, Ayala-Soto JG, Chavez-Flores D and Hernandez-Ochoa L (2018). Comparison of oil content and fatty acids profile of western Schley, Wichita, and native pecan nuts cultured in Chihuahua, Mexico. Journal of Lipids, 2018: 4781345. https://doi.org/10.1155/2018/4781345

Sevimli-Gur C, Gezgin Y, Oz A, Al Sharqi S, Gumus ZP and Dunford NT (2021). Biological activity of the extracts from pecan shelling industry by-products. Transactions of the American Society of Agricultural and Biological Engineers, 64(3):869-877. https://elibrary.asabe.org/abstract.asp?aid=52190

Stein HH, Lagos LV and Casas GA (2016). Nutritional value of feed ingredients of plant origin fed to pigs. Animal Feed Science and Technology, 218:33-69. https://doi.org/10.1016/i.anifeedsci.2016.05.003

Thiex NJ, Anderson S and Gildemeister B (2003). Crude fat, diethyl ether extraction, in feed, cereal grain, and forage (randall/soxtec/submersion method): collaborative study. Journal of AOAC International, 85(5): 888-889. https://doi.org/10.1093/jaoac/86.5.888

Velayudhan djkslakd DE, Kim IH and Nyachoti CM (2015). Characterization of dietary energy in swine feed and feed ingredients: a review of recent research results. Asian-Australasian Journal of Animal Science, 28(1):1-13. DOI: https://doi.org/10.5713/ajas.14.0001r

Wilfart A, Espagnol S, Dauguet S, Tailleur A, Gac A and Garcia-Launay (2016). ECOALIM: a dataset of environmental impacts of feed ingredients used in French animal production. PloS One, 11:e0167343. DOI: https://doi.org/10.1371/journal.pone.0167343

Windisch W, Shedle K, Plitzner C and Kroismayr A (2008). Use of phytogenic products as feed additives for swine and poultry. Journal of Animal Science, 86 (suppl. 14): E140-E148. DOI: https://doi.org/10.2527/jas.2007-0459

Zijlstra RT and Beltranena E (2009). Variability of quality in biofuel co-products. In: PC Garnsworthy and J Wiseman (Editors), Recent advances in animal nutrition. Nottingham Academic Press, Nottingham, UK, p, $313-326$. https://www.cabdirect.org/cabdirect/abstract/20093114497

Zijlstra RT and Beltranena E (2013). Swine convert co-products from food and biofuel industries into animal protein for food. Animal Frontiers, 3(2):48-53. DOI: https://doi.org/10.2527/af.2013-0014 